\title{
Effects of temperature on gene expression in embryos of the coral
} Montastraea faveolata

\author{
Christian R Voolstra ${ }^{\dagger 1,2}$, Julia Schnetzer ${ }^{\dagger 2}$, Leonid Peshkin³, Carly J Randall4, \\ Alina M Szmant ${ }^{4}$ and Mónica Medina*2
}

\begin{abstract}
Address: ${ }^{1}$ Red Sea Research Center, King Abdullah University of Science and Technology (KAUST), Thuwal, Saudi Arabia, ${ }^{2}$ School of Natural Sciences, University of California, Merced, 5200 North Lake Road Merced, CA 95343, USA, ${ }^{3}$ Systems Biology, Harvard Medical School, 200 Longwood Ave, W Alperts \#536, Boston, MA 02115, USA and ${ }^{4}$ Center for Marine Science, University North Carolina Wilmington, 5600 Marvin K Moss Lane, Wilmington, NC 28409, USA

Email: Christian R Voolstra - christian.voolstra@kaust.edu.sa; Julia Schnetzer - jschnetzer@gmail.com; Leonid Peshkin - pesha@hms.harvard.edu; Carly J Randall - cjr2021@uncw.edu; Alina M Szmant - szmanta@uncw.edu; Mónica Medina* - mmedina@ucmerced.edu

* Corresponding author †Equal contributors
\end{abstract}

Published: 23 December 2009

BMC Genomics 2009, 10:627 doi:10.1|86/|47|-2/64-10-627

This article is available from: http://www.biomedcentral.com/I47I-2/64//0/627

(c) 2009 Voolstra et al; licensee BioMed Central Ltd.

This is an Open Access article distributed under the terms of the Creative Commons Attribution License (http://creativecommons.org/licenses/by/2.0), which permits unrestricted use, distribution, and reproduction in any medium, provided the original work is properly cited.
Received: 2 April 2009

Accepted: 23 December 2009

\begin{abstract}
Background: Coral reefs are expected to be severely impacted by rising seawater temperatures associated with climate change. This study used cDNA microarrays to investigate transcriptional effects of thermal stress in embryos of the coral Montastraea faveolata. Embryos were exposed to $27.5^{\circ} \mathrm{C}, 29.0^{\circ} \mathrm{C}$, and $31.5^{\circ} \mathrm{C}$ directly after fertilization. Differences in gene expression were measured after 12 and 48 hours.

Results: Analysis of differentially expressed genes indicated that increased temperatures may lead to oxidative stress, apoptosis, and a structural reconfiguration of the cytoskeletal network. Metabolic processes were downregulated, and the action of histones and zinc finger-containing proteins may have played a role in the long-term regulation upon heat stress.

Conclusions: Embryos responded differently depending on exposure time and temperature level. Embryos showed expression of stress-related genes already at a temperature of $29.0^{\circ} \mathrm{C}$, but seemed to be able to counteract the initial response over time. By contrast, embryos at $31.5^{\circ} \mathrm{C}$ displayed continuous expression of stress genes. The genes that played a role in the response to elevated temperatures consisted of both highly conserved and coral-specific genes. These genes might serve as a basis for research into coral-specific adaptations to stress responses and global climate change.
\end{abstract}

\section{Background}

Coral reefs are based on the symbiotic relationship between corals and photosynthetic dinoflagellates of the genus Symbiodinium, also known as zooxanthellae, and exist within a narrow temperature range. The optimum temperature for adult scleractinian corals is between $25^{\circ} \mathrm{C}$ and $29.0^{\circ} \mathrm{C}$ [1]. As climate change becomes an increasing threat to the biosphere, corals are among the first organisms to suffer from the consequences of global warming [2]. Heat stress in reef-building corals affects the coral hosts and their algal symbionts, but the relative sensitivity of both to thermal stress is uncertain [3]. The first visual 
sign of heat stress to the coral holobiont (i.e. host, symbionts, and associated microorganisms) is bleaching, i.e. the loss of photosynthetic symbionts [4].

Studies on heat stress in adult corals have shown that processes such as $\mathrm{Ca}^{2+}$ homeostasis, cytoskeletal organization, cell death, calcification, metabolism, protein synthesis, and heat shock protein activity are affected among others [5-9]. Many of the identified genes from these studies code for known stress-responsive proteins that are shared among eukaryotes. Furthermore, it has been shown that an increase in temperature leads to oxidative stress in corals [10], with evidence pointing towards photosystem II of the algal symbiont as the main source of reactive oxygen species (ROS) [11-13].

Larvae play an important role in coral reef ecosystems as they form the starting point of the bentho-pelagic lifecycle of a coral [14]. From a molecular and genetic perspective, coral embryos/larvae represent an interesting system, as many species initially lack endosymbionts. Hence, it is possible to measure the effect of temperature on corals without the confounding factor of symbionts and their different physiologies. Studies on coral larvae show that increasing temperatures affect fertilization, embryogenesis, development, survival, and settlement $[15,16]$. However, molecular studies that assess transcriptome-wide changes in gene expression upon increasing temperatures in coral embryos and larvae have not yet been published.

In this study, we exposed newly fertilized azooxanthellate coral embryos of the Caribbean species Montastraea faveolata (Cnidaria, Anthozoa, Hexacorallia) to a range of temperatures: 1) a permissive temperature of $27.5^{\circ} \mathrm{C}$ that is known to be non-stressful; 2) $29.0^{\circ} \mathrm{C}$, which is a normal summer seawater temperature in the Caribbean Sea during the spawning period; and 3) an elevated temperature of $31.5^{\circ} \mathrm{C}$, which has been observed during the late summer of bleaching years such as 2005. Transcriptomic changes were assayed with microarrays at 12 and 48 hours after fertilization. Based on our analysis of differentially expressed genes we devised a model that proposes that genes that play a role in system perturbation, system maintenance, and system regulation are affected upon heat stress. This study is the first transcriptome-wide analysis of heat stress in coral embryos and our data provide first insights into the relevant genes and adaptive capabilities of coral embryos in light of projected increases in seawater temperatures.

\section{Results and Discussion \\ Developmental differences}

We compared developing coral embryos after 16 and 50.5 hours that were raised at $27.5^{\circ} \mathrm{C}, 29.0^{\circ} \mathrm{C}$, and $31.5^{\circ} \mathrm{C}$ (Table 1). Albeit offset by 4 and 2.5 hours to the samples on the microarray, the developmental stages of these embryos should reflect the embryos that were used for microarray analysis. We were not able to identify developmental differences based on larval morphology in regard to the different temperatures. However, tools for external classification of developmental stages are limited. Hence, changes in development probably exist that are not detected morphologically, but confound gene expression nevertheless. Studies have shown that some coral species do show faster development upon increasing temperatures, whereas others do not $[15,16]$.

We found a higher number of misshapen embryos after 12 hours at $29.0^{\circ} \mathrm{C}$ and $31.5^{\circ} \mathrm{C}$ in comparison to embryos kept at $27.5^{\circ} \mathrm{C}$. However, after 48 hours, the proportion of misshapen embryos decreased for embryos kept at $29.0^{\circ} \mathrm{C}$ and $31.5^{\circ} \mathrm{C}$, and increased for embryos kept at $27.5^{\circ} \mathrm{C}$. Negri et al. [15] observed an increase in frequency of abnormalities in embryos of Acropora millepora when exposed to temperatures of $32{ }^{\circ} \mathrm{C}$ or higher, but in our case the number of misshapen embryos was not consistent with an increase in temperature. However, proper larval development is critical for larval settlement, which in turn is required for individuals to be incorporated into a population. We have not followed up development of larvae until settlement, but the number of misshapen embryos indicates that it is a confounding factor to gene expression measurements.

Table I: Developmental stages of coral embryos after 16 and 50.5 hours raised at $27.5^{\circ} \mathrm{C}, 29.0^{\circ} \mathrm{C}$, and $31.5^{\circ} \mathrm{C}$

\begin{tabular}{|c|c|c|c|c|c|c|}
\hline \multirow[b]{2}{*}{ Temperature } & \multirow[b]{2}{*}{ Hours after Fertilization } & \multicolumn{5}{|c|}{ Number of embryos in that stage } \\
\hline & & Blastula & Invaginated & Gastrula & Planula & Irregular \\
\hline $27.5^{\circ} \mathrm{C}$ & 16 & 98 & 0 & 0 & 0 & 3 \\
\hline $29.0^{\circ} \mathrm{C}$ & 16 & 88 & 3 & 0 & 0 & 9 \\
\hline $31.5^{\circ} \mathrm{C}$ & 16 & 98 & 2 & 0 & 0 & 9 \\
\hline $27.5^{\circ} \mathrm{C}$ & 50.5 & 0 & 0 & 88 & 1 & 11 \\
\hline $29.0^{\circ} \mathrm{C}$ & 50.5 & 0 & 0 & 96 & 0 & 4 \\
\hline $31.5^{\circ} \mathrm{C}$ & 50.5 & 0 & 0 & 97 & 0 & 4 \\
\hline
\end{tabular}




\section{Embryo transcriptomes are affected in a time- and temperature-dependent manner}

We constructed a radial tree of hierarchically clustered gene expression data to infer relatedness across different temperature regimes and time points (Figure 1). We found that samples clustered according to time point, i.e. all 12 hour samples were distant from all 48 hour samples. Hence, the differences between all temperature treatments for a given time point were much smaller than between temperatures for both time points. We suggest that the stark separation between both time points is attributable to the different developmental stages the embryos were in (Table 1) rather than differences due to temperature treatment, which is why we decided to not compare directly between time points. A recent study by Grasso et al. [17] found that 1,084 of 5,081 unique genes were differentially expressed during early coral development. Thus, a significant part of the coral embryo transcriptome seems to change during development, which supports the distinctive separation we see between 12 and 48 hour old embryos.

For the 12 hour time point, embryos kept at $29.0^{\circ} \mathrm{C}$ and $31.5^{\circ} \mathrm{C}$ cluster together and are separated from embryos kept at $27.5^{\circ} \mathrm{C}$. We interpret this pattern as an indication that embryos initially respond similarly to increased temperatures. However, the distance between all 12 hour nodes is small. By contrast, after 48 hours embryos kept at $27.5^{\circ} \mathrm{C}$ cluster together with embryos kept at $29.0^{\circ} \mathrm{C}$ and are notably separated from embryos kept at $31.5^{\circ} \mathrm{C}$. This indicates that over time the transcriptomic pattern of embryos kept at $29.0^{\circ} \mathrm{C}$ becomes more similar to those raised at $27.5^{\circ} \mathrm{C}$.

\section{Molecular signature of temperature increase in coral embryos}

We identified a total of 232 differentially expressed genes for embryos kept at $29.0^{\circ} \mathrm{C}$ after 12 hours post fertilization, and 101 differentially expressed genes for embryos at this temperature after 48 hours. For embryos kept at $31.5^{\circ} \mathrm{C}$, we identified 218 differentially expressed genes after 12 hours, and 285 after 48 hours (Additional File 1). Genes were defined as up- or downregulated in regard to the expression of that gene in the $27.5^{\circ} \mathrm{C}$ temperature sample. Please note that the fertilization temperature was $30^{\circ} \mathrm{C}$, and thus higher than two of the experimental temperatures $\left(27.5^{\circ} \mathrm{C}\right.$ and $\left.29.0^{\circ} \mathrm{C}\right)$ and lower than the third $\left(31.5^{\circ} \mathrm{C}\right)$. Gene expression might be partially affected by this circumstance as larvae at $27.5^{\circ} \mathrm{C}$ and $29^{\circ} \mathrm{C}$ experienced a higher initial incubation temperature, and larvae at $31.5^{\circ} \mathrm{C}$ experienced a lower initial incubation temperature. This might especially affect the 12 hour time point as larvae were kept at the treatment temperatures for only 10 hours. Annotated differentially expressed genes were assorted manually into different categories depending on their function or process they are involved in (based on BLAST, HMMER, GO, and InterPro results). Genes were associated with the following categories: response to stress, response to oxidative stress, apoptosis, immune system, cytoskeleton, proliferation/growth/development, ribosomes/translation, degradation, metabolism, electron transport, transport, signalling, RNA, DNA, and regulation of transcription (Additional File 2). These categories were then assembled into the three main groups of (1) system perturbation, (2) system maintenance, and (3) system regulation. The system perturbation group contained all the genes that became differentially expressed as a direct consequence of temperature exposure, i.e. genes assorted to a response to stress, a response to oxidative stress, apoptosis, cytoskeleton, and the immune system. Genes that were assorted to cytoskeleton, proliferation/ growth/development, ribosomes/translation, degradation, metabolism, electron transport, and transport were united into the group system maintenance. This group contained all those genes that play roles in housekeeping processes or processes related to continuation of the biology of a cell. All genes that were assorted to signaling, RNA, DNA, and regulation of transcription were referenced in the group system regulation as these proteins play roles in regulatory processes in a cell.

\section{System perturbation genes}

We identified stress-responsive genes such as Stressresponse protein NST1 (AOSB460), Universal stress protein (AOSF1521), Drought-induced protein RDI (CAON1066), Recombination repair protein 1 (AOSB392), and Senescence-associated protein (CAOO2479, CAOO703) among others. We found a consistent down-regulation of members of the SCRiPs gene family across all time points and temperatures analyzed. This gene family has only been recently identified [18], and has been shown to be downregulated upon thermally induced bleaching in M. faveolata [6].

We did not identify a significant upregulation of heat shock proteins (HSPs) at any time point and temperature. This could be due to a maximum temperature increase of up to $31.5^{\circ} \mathrm{C}$. Most studies on proteins have not reported the expression of heat shock proteins at temperatures lower than $33^{\circ} \mathrm{C}[5,8]$. In addition, our arrays contained only homologs of a 90-kda heat shock protein (HSP90) (AOSF1451) and a $97 \mathrm{kDa}$ heat shock protein (CAOO2018). Both genes displayed higher expression in embryos kept at $31.5^{\circ} \mathrm{C}$ after 12 hours, but not significantly so (data not shown). We did, however, identify heat shock transcription factor 1 (CAON1605) to be upregulated after 12 hours at $31.5^{\circ} \mathrm{C}$. Heat shock transcription factors (HSFs) regulate the induction of many HSPs and other proteins $[19,20]$. In particular, HSF1 has been indentified as the primary transcription factor 


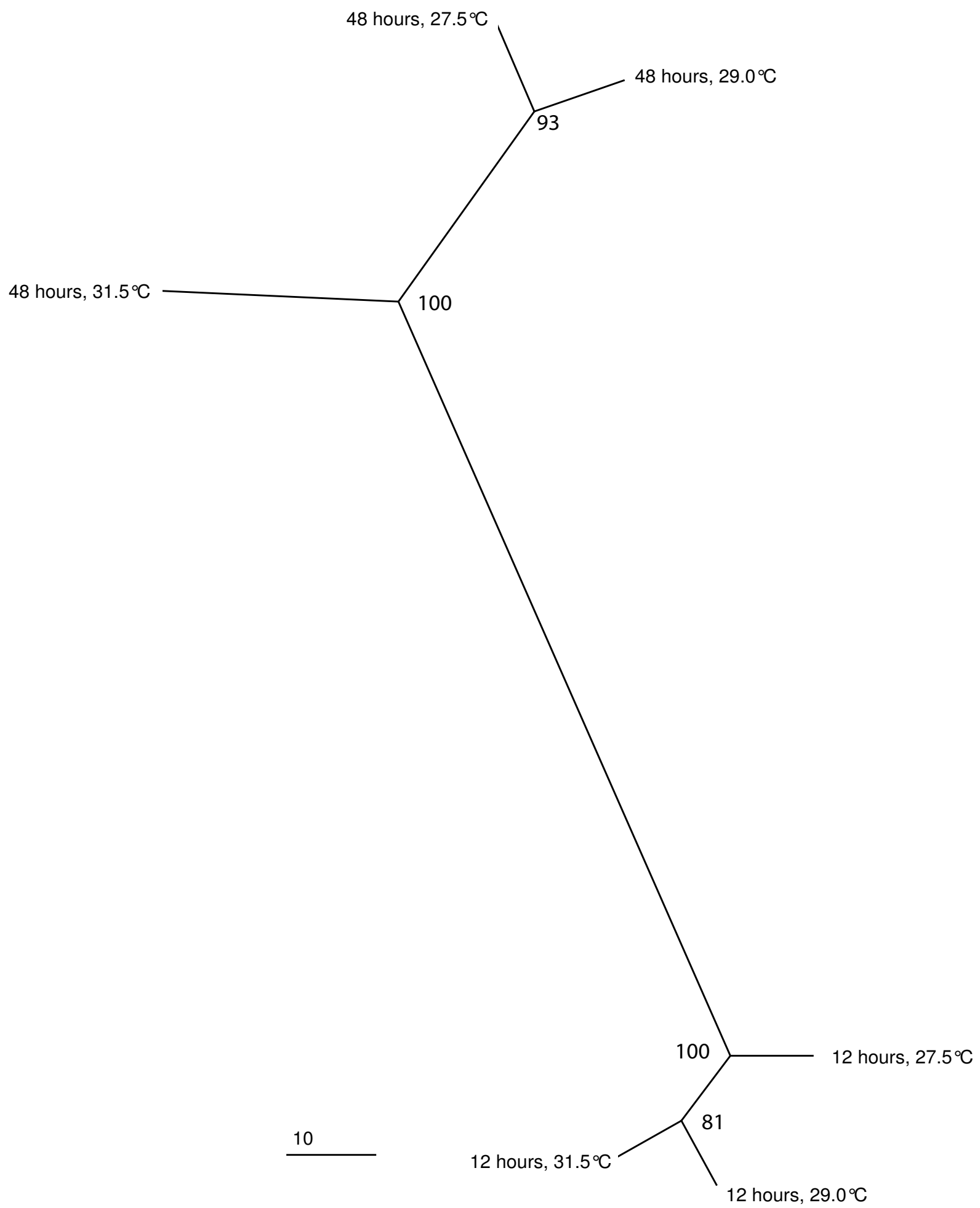

Figure I

Radial tree of hierarchically clustered transcriptomes of embryos of $\boldsymbol{M}$. faveolata. Embryos were raised at three different temperatures $\left(27.5^{\circ} \mathrm{C}, 29.0^{\circ} \mathrm{C}, 31.5^{\circ} \mathrm{C}\right)$, and gene expression was measured at 12 and 48 hours after fertilization. Support values are based on I,000 bootstrap replicates. Scale bar at lower left corner displays overall Euclidean distance between expression vectors. 
responsible for the transcriptional response to heat stress in mammalian cells [21]. In addition, our set of differentially expressed genes indicated increased rates of protein misfolding, degradation, and DNA damage as stated in succeeding sections. Hence, we assume that the treatment temperatures applied were high enough to have structural effects on nucleic acids and proteins. This in turn suggests that both temperatures, $29.0^{\circ} \mathrm{C}$ and $31.5^{\circ} \mathrm{C}$, are stressful, and that rather the buffering capacity of heat shock proteins was being compromised in this experiment.

In the category response to oxidative stress we found a high overlap among the upregulated genes after 48 hours for embryos kept at $29.0^{\circ} \mathrm{C}$ and $31.5^{\circ} \mathrm{C}$. At both temperatures cytochrome p450 (CAON1879), soma ferritin (CAON1101), catalase (AOSF550), and peroxidasin-like protein (AOSF997) were upregulated as a consequence of exposure to increased temperatures. The upregulation of oxidative stress genes indicates that, as in adult corals, an increase in temperature leads to oxidative stress in coral embryos [11]. Whereas cytochrome p450, soma ferritin, and catalase displayed a similar change in expression at both temperatures, peroxidasin-like protein was highly upregulated (> 12-fold) in embryos exposed to $31.5^{\circ} \mathrm{C}$. Peroxidasin is a supposedly multifunctional protein that plays a role in several biological processes such as oxidation reduction, removal of apoptotic cells, and cross-linking and stabilizing of the extracellular matrix [22]. We suggest that peroxidasin-like protein might provide a useful candidate as a coral heat stress biomarker for the following reasons: 1) Peroxidasin-like protein seems to be concordantly upregulated in embryos exposed for prolonged periods of time to elevated temperatures, 2) it showed a difference in upregulation depending on the temperature level that embryos were exposed to which gives rise to the possibility to not only assess current stress levels, but past stress levels, and 3) it has been shown to be upregulated upon heat stress in adult coral [6]. Further studies on peroxidasin-like protein with a higher number of samples and coral species must be conducted in order to yield insights into the identity and applicability of this protein as a heat stress biomarker.

We find evidence for activation of apoptosis upon exposure to increased temperatures. We identified a homolog of activating transcription factor 5 (CAON612) to be upregulated after 12 hours for both temperatures, and after 48 hours for embryos raised at $31.5^{\circ} \mathrm{C}$. This gene plays an essential role in cell growth, survival and apoptosis $[23,24]$. Moreover, we identified a number of downregulated apoptosis-related genes, mainly in the late time point. The genes were autophagy-related protein 16 (CAOO2671), calreticulin (AOSC448), and Proapoptotic Caspase Adapter Protein (AOSF761). Downregulation of calreticulin has been shown to activate oxidative stress and cell death [25]. Similarly, downregulation of proapoptotic caspase adapter protein (PACAP) has been shown to expose neuronal cells to oxidative stress-induced apoptosis [26-28].

\section{System maintenance genes}

Differential expression in developmental- and growthrelated genes could be a consequence of differences in development for a given time point. For this reason, we decided that the implication of differentially expressed genes of this category remains to be elucidated. Nevertheless, downregulation of calmodulin (AOSF573) has been shown to be a sign of oxidative stress [29]. Furthermore, we detected downregulation of ribosomal and translation-associated proteins. Downregulation of ribosomal proteins as a consequence of heat shock has been shown in Drosophila melanogaster and yeast [30,31]. Most of the genes in the category degradation were ubiquitin-related genes. Protein degradation is considered a general consequence of heat stress as elevated temperatures lead to increased rates of misfolding. In accordance with our findings of a downregulation of protein biosynthesis (which would indicate a downregulation of overall metabolism), we found a stronger down- than upregulation of metabolism-related genes. We also found a downregulation of genes related to electron transport in oxidative phosphorylation that might further indicate that metabolism is downregulated. For instance, cytochrome b5 (CAON1668) and NADH-ubiquinone oxidoreductase 7 (CAON943) were downregulated across all time points and temperatures, mitochondrial ATP synthase $f$ chain (AOSC720) in both time points at $29.0^{\circ} \mathrm{C}$ and in the late time point at $31.5^{\circ} \mathrm{C}$.

\section{System regulation genes}

We found a homolog of histone H3.3 consistently downregulated across all treatments and time points, and a homolog of histone H2A.V downregulated after 48 hours for both treatment temperatures. Histone proteins are post-translationally modified and are part of chromatinbased regulatory mechanisms that modulate the accessibility of genetic information [32]. It remains to be determined what the direct consequences of histone downregulation in temperature-treated coral embryos are, but it has been shown that downregulation of histone gene expression is used as a mechanism to prevent cells from further replicating upon DNA damage [33].

A number of upregulated genes contained zinc finger motifs. Zinc finger proteins comprise the largest family of regulatory proteins in mammals and bind to cognate DNA (e.g. transcription factors), RNA, or protein [34]. Specifically proteins that use $\mathrm{C} 2 \mathrm{H} 2$ zinc fingers have been found to recognize histones for acetylation and/or methylation $[35,36]$. Although tempting, it remains to be 
determined if the histones and zinc finger genes we identified here are functionally connected.

\section{Model of heat stress in coral embryos}

Based on our analysis and assignment of annotated differentially expressed genes, we devised a model of heat stress in coral embryos (Figure 2). Upon temperature increase, cells respond with regulation of genes playing a role in system perturbation, system maintenance, and system regulation. Heat stress induces differential expression of stress-responsive genes. This in turn results in differential expression of genes involved in the response to oxidative stress as heat stress stimulates the production of ROS $[37,38]$. High levels of oxidative stress in turn have been linked to programmed cell death pathways and cytoskeletal changes [39]. Furthermore, heat stress causes a general downregulation of metabolic processes in coral embryos. As a consequence, ribosome biosynthesis, metabolism, and oxidative phosphorylation are downregulated. These processes are all interconnected. Additionally, heat stress causes misfolding of proteins, which in turn affects the regulation of the protein degradation machinery. On an upstream level, Histone proteins regulate downstream gene expression, and zinc finger proteins might modify those in turn. Please note that this model is based on incomplete transcriptomic data and manual assortment of differentially expressed genes, and therefore subject to change. Furthermore, due to logistical constraints, we were not able to include true biological replicates. Ideally, three to five independent replicated cultures should have been analyzed per treatment and time point to evaluate the potentially contribution of so-called "jar effects" (i.e. the differences between supposedly identical cultures) into the observed gene expression variation. Although jar effects represent a problem for our analysis, we hope that most of the observed gene expression patterns represent the true response to the treatments, because 1) our results are in correspondence with results from other heat stress studies in other organisms, 2) we find a stronger stress response in larvae treated at higher temperatures, and 3) a similar study that we conducted with Acropora palmata larvae in which we did assay biological replicates gave similar results (data not shown). We therefore acknowledge that implications drawn from these data are limited and follow-up studies (e.g. qPCR) with proper biological replication are necessary to validate results and conclusions presented here. Future efforts should concentrate on comparing transcriptomic responses to different stressors in coral embryos in order to identify a set of common and specific key response genes. These key genes could then serve as a repository for stressor-specific biomarkers as well as for research into coral-specific adaptations to stress responses and global climate change.

\section{Conclusions}

Our aim was to look at differential gene expression in coral embryos at temperatures that are known to be nonstressful to corals $\left(27.5^{\circ} \mathrm{C}\right)$ in comparison to 1$)$ late summer temperatures during spawning that corals seem to tolerate $\left(29.0^{\circ} \mathrm{C}\right)$ and 2$)$ elevated late summer temperatures

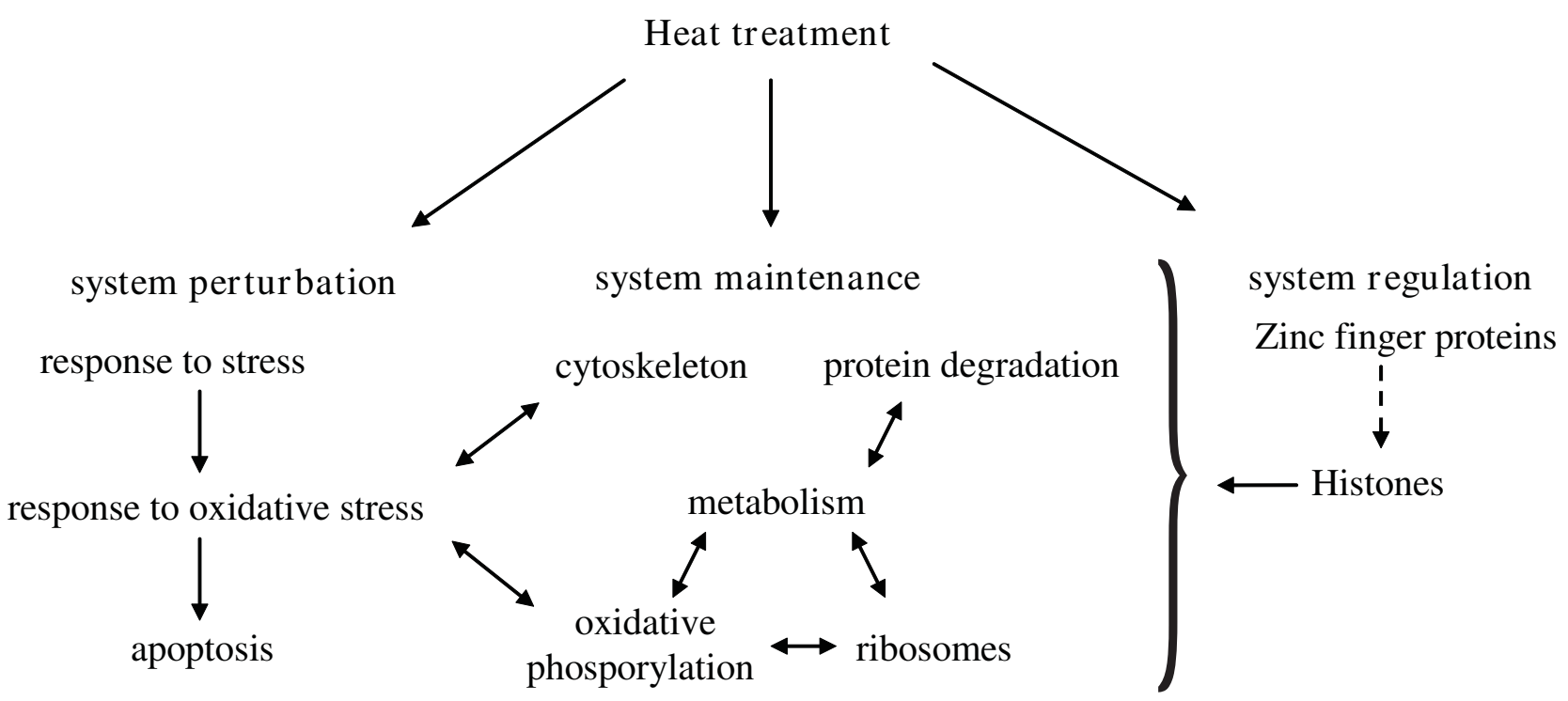

\section{Figure 2}

Model of heat stress response in coral embryos. Upon heat treatment, coral embryos respond with regulation of genes playing a role in system perturbation, system maintenance, and system regulation. These functional groups are interconnected. 
observed during years when adult bleaching is more pronounced $\left(31.5^{\circ} \mathrm{C}\right)$. For this reason, we exposed our embryos to a more constant and gentle increase in water temperature rather than a short term heat shock. Despite the lack of biological replicates in this study, our data indicate that effects of temperature on coral embryos depend on the duration and the degree of temperature change. Embryos at $29.0^{\circ} \mathrm{C}$ are physiologically responsive and show expression of stress-related genes, but seem to be able to counteract the temperature situation over time. Embryos at $31.5^{\circ} \mathrm{C}$, however, are not able to recover during prolonged exposure periods and continuously express stress-related genes.

\section{Methods \\ Sample collection}

Gamete bundles containing both egg and sperm of Montastraea faveolata were collected from multiple colonies during spawning on the MesoAmerican Barrier Reef in Puerto Morelos, Mexico $\left(20^{\circ} 52^{\prime} 28.77^{\prime \prime} \mathrm{N}\right.$ and $\left.86^{\circ} 51^{\prime} 04.53^{\prime \prime} \mathrm{W}\right)$ on September $3^{\text {rd }}, 2007$. Subsequent embryonic and larval rearing and experimental procedures were carried out at the Unidad de Sistemas Arrecifales of the Instituto de Ciencias del Mar y Limnología (ICMYL) of the Universidad Nacional Autónoma de México (UNAM). Spawn collection and fertilization were carried out at $30.0^{\circ} \mathrm{C}$, and followed previously published protocols $[40,41]$. Two hours after eggs were fertilized, embryos were transferred into bins containing $5 \mu \mathrm{m}$ filtered seawater (FSW) and were raised at $27.5^{\circ} \mathrm{C}, 29.0^{\circ} \mathrm{C}$ and $31.5^{\circ} \mathrm{C}$. Our temperature exposure system is described in detail in [42] and controlled temperature to to $\pm 0.2^{\circ} \mathrm{C}$. Batch cultures of embryos for this work were contained in $500 \mathrm{~mL}$ plastic containers suspended in the temperature baths by a foam rack. Each container was seeded with ca. 5,000 embryos, and embryos for a given temperature were raised in three different containers. Water in the containers was changed twice per day with water that was preheated to the treatment temperature prior to use. Approximately 500 embryos from each of the three containers for a given temperature were sampled and combined after 12 and 48 hours. This gave rise to a single sample of 1,500 embryos for each temperature and time point that was used for subsequent RNA isolation. Each of these RNA isolations was used for 3 technical microarray replicates. Embryos were immediately transferred into RNAlater (Ambion), and incubated overnight in the refrigerator. Subsequently, soaked embryos were frozen at $-80^{\circ} \mathrm{C}$ and returned to the laboratory for analysis. To examine the time course of development, approximately 100 embryos were sampled from each temperature every 4 to 12 hours along the developmental time course. Embryos were sampled from the $500 \mathrm{~mL}$ culture containers from the same embryo pool as the microarray samples. Embryos were fixed in 2\% Glutaraldehyde in $0.05 \mathrm{M}$ sodium cacodylate buffer and kept at $4{ }^{\circ} \mathrm{C}$. The samples were then returned to the laboratory for microscopic examination to determine developmental stages. Experimental research followed internationally recognized guidelines according to CITES (the Convention on International Trade in Endangered Species of Wild Fauna and Flora), permit number: MX-HR-007-MEX. No ethical approval was required for any of the experimental research described here.

\section{RNA, Hybridization, Microarrays}

Microarray protocols followed those established by the Center for Advanced Technology at the University of California, San Francisco http://cat.ucsf.edu/. 1,314 PCRamplified cDNAs from $M$. faveolata were spotted in duplicate on poly-L-lysine-coated slides yielding a microarray with 2,628 total features. Spotted cDNAs were chosen from EST libraries described in Schwarz et al. [43]. 43\% of the 1,314 cDNAs had functional annotations as determined by tBLASTx and BLASTx analyses (E-value cut-off 1e-5) against the GenBank non-redundant DNA and protein databases (nr). All clones are accessible via our database at http://sequoia.ucmerced.edu/SymBioSys/ index.php.Total RNA of approximately 1,500 frozen coral embryos was isolated using Qiazol lysis reagent (QIAGEN) according to manufacturer's instructions. Embryos were homogenized for 2 minutes using a Mini-Beadbeater (Biospec) with $0.1 \mathrm{~mm}$ and $0.55 \mathrm{~mm}$ silica beads to break up cellular structures. RNA pellets were cleaned further with RNeasy Mini columns (Qiagen). RNA quantity and integrity was assessed with a NanoDrop ND-1000 spectrophotometer and an Agilent 2100 Bioanalyzer, respectively. For all experiments, $1 \mu \mathrm{g}$ of total RNA was amplified using the MessageAmp II aRNA kit (Ambion). For cDNA synthesis, $3 \mu \mathrm{g}$ of aRNA per sample were primed with $3.5 \mathrm{nmoles}$ of random pentadecamers for 10 minutes at $70^{\circ} \mathrm{C}$. Reverse transcription (RT) lasted for 2 hours at $50^{\circ} \mathrm{C}$ using a master mix containing a $4: 1$ ratio of aminoallyl-dUTP to TTP. Following RT, single-stranded RNA was hydrolyzed by incubating RT reactions in $10 \mu \mathrm{L}$ $0.5 \mathrm{M}$ EDTA and $10 \mu \mathrm{L} 1 \mathrm{M} \mathrm{NaOH}$ for 15 minutes at $65^{\circ} \mathrm{C}$. After hydrolysis, RT reactions were cleaned using the MinElute Cleanup kit (Qiagen). Cy3 and Cy5 dyes (GE Healthcare) were dissolved in $18 \mu \mathrm{L} \mathrm{DMSO}$, and the coupling reactions lasted for 2 hours at room temperature in the dark. Dye-coupled cDNAs were cleaned using the MinElute Cleanup kit (Qiagen). Prior to hybridization, microarrays were post-processed by: 1) UV crosslinking at 60 $\mathrm{mJ} ; 2)$ a "shampoo" treatment $(3 \times$ SSC, $0.2 \%$ SDS at $65^{\circ} \mathrm{C}$ ); 3) blocking with $5.5 \mathrm{~g}$ succinic anhydride dissolved in $335 \mathrm{~mL}$ 1-methyl-2-pyrrilidinone and $15 \mathrm{~mL}$ sodium borate; and 4) drying via centrifugation. Appropriate Cy3 and Cy5 labeled cDNAs were mixed together in a hybridization buffer containing $0.25 \%$ SDS, $25 \mathrm{mM}$ HEPES, and $3 \times$ SSC. The hybridization mixtures were 
boiled for 2 minutes at $99^{\circ} \mathrm{C}$, then allowed to cool at room temperature for 5 minutes. The cooled hybridization mixtures were pipetted under an mSeries Lifterslip (Erie Scientific), and hybridization took place in Corning hybridization chambers overnight at $63^{\circ} \mathrm{C}$. Microarrays were washed twice in $0.6 \times$ SSC and $0.01 \%$ SDS followed by a rinse in $0.06 \times$ SSC and dried via centrifugation. Slides were immediately scanned using an Axon 4000B scanner. The experimental setup followed a reference design, i.e. all samples were hybridized against the same pool made up of equal amounts of RNA from all samples. We used three technical replicates for each temperature. Common reference samples were labelled with Cy3, temperature treatment samples with Cy5.

\section{Data analysis}

For the microarrays, slides were scanned as described in [6]. Spot intensities were extracted and background was subtracted using TIGR Spotfinder 2.2.4 [44]. Data was normalized using printtip-specific LOWESS in TIGR MIDAS 2.19 [44]. Data have been deposited in NCBI's Gene Expression Omnibus [45] and are accessible through GEO Series accession number GSE15088. The ratio between the fluorescence intensity of the two channels was then used as input for BAGEL (Bayesian Analysis of Gene Expression Levels) [46]. This analysis yielded relative expression level estimates for 1,218 genes. We used the conservative gene-by-gene criterion of non-overlapping $95 \%$ credible intervals to regard a gene as significantly differentially expressed. Genes were defined as upor downregulated in regard to the expression of that gene in the $27.5^{\circ} \mathrm{C}$ temperature sample. Fold-changes were calculated as the ratio of the higher expression level to the lower expression level for the temperature conditions to be compared. Significant genes were assorted into categories according to their respective biological processes, cellular components, or manually defined categories. Putative functions were based on GO molecular functions, or manual assessment through literature searches and perusal of protein databases (e.g. PFAM and InterPro). Transcriptome trees were constructed by hierarchical clustering of arrays by the average linkage algorithm on the ratio of the relative expression level as estimated by BAGEL in TIGR TMeV 3.1 [44]. TreeView [47] was used to display the tree.

\section{Authors' contributions}

CRV wrote the manuscript, designed the microarray study, and analyzed the microarray data. JS carried out microarray hybridizations, data extraction and analyses, and wrote the manuscript. LP assisted in microarray data analysis. CJR and AMS raised and provided coral embryos. AMS conceived of the study, and participated in its design and coordination. MM participated in study design, coor- dination, and wrote the manuscript. All authors read and approved the final manuscript.

\section{Additional material}

\author{
Additional file 1 \\ Differentially expressed genes as determined by BAGEL. Fold changes \\ are determined in relation to the expression of a gene at $27.5^{\circ} \mathrm{C}$. Func- \\ tional annotation as deduced from BLASTX, GO, and UniProtKB. All \\ CloneIDs are accessible at http://sequoia.ucmerced.edu/SymBioSys/ \\ index.php. \\ Click here for file \\ [http://www.biomedcentral.com/content/supplementary/1471- \\ 2164-10-627-S1.XLS]

\section{Additional file 2} \\ Differentially expressed genes assorted to the three main groups sys- \\ tem perturbation, system maintenance, and system regulation. FC: \\ fold change. All CloneIDs are accessible at http://sequoia.ucmerced.edu/ \\ SymBioSys/index.php. \\ Click here for file \\ [http://www.biomedcentral.com/content/supplementary/1471- \\ 2164-10-627-S2.XLS]
}

\section{Acknowledgements}

The authors would like to thank the anonymous reviewers for valuable comments on the manuscript. Furthermore, we thank the members of the Medina laboratory at UC Merced, the Szmant laboratory at UNCW, and the members of the photobiology group in Puerto Morelos, especially Roberto Iglesias-Prieto and Ania Banaszak, for aid in collecting the coral spawn. We also thank Laura Hiles for the microscopic analysis of the developmental stages. The larval culture and temperature exposure experiment was funded by the Connectivity Working Group of the Global Environment Fund Targeted Research and Capacity Building Project to AMS, and by funding from UNCW Academic Affairs to AMS. The microarray analysis was supported through a UC MEXUS-CONACYT Grant to MM, NSF awards to MM (BE-GEN 0313708 and IOS 0644438), start-up funds from UC Merced to MM, and a UC Merced GRC grant to MM.

\section{References}

I. Stoddart DR: Ecology and morphology of recent coral reefs. Biological Reviews 1969, 44:433-498.

2. Knowlton N: The future of coral reefs. Proceedings of the National Academy of Sciences of the United States of America 200I, 98:5419-5425.

3. Edmunds PJ, Gates RD: Has Coral Bleaching Delayed Our Understanding of Fundamental Aspects of Coral-Dinoflagellate Symbioses? BioScience 2003, 53:976-980.

4. Williams EH, Bunkley-Williams L: The world-wide coral reef bleaching cycle and related sources of coral mortality. Atoll Res Bull 1990, 335: I-7I.

5. Black NA, Voellmy R, Szmant AM: Heat Shock Protein Induction in Montastraea faveolata and Aiptasia pallida Exposed to Elevated Temperatures. Biol Bull 1995, I88:234-240.

6. DeSalvo MK, Voolstra CR, Sunagawa S, Schwarz JA, Stillman JH, Coffroth MA, Szmant AM, Medina M: Differential gene expression during thermal stress and bleaching in the Caribbean coral Montastraea faveolata. Mol Ecol 2008, 17:3952-3971.

7. Fang L-S, Huang S-P, Lin K-L: High temperature induces the synthesis of heat-shock proteins and the elevation of intracellular calcium in the coral Acropora grandis. Coral Reefs 1997, 16:|27-|3|. 
8. Sharp VA, Brown BE, Miller M: Heat shock protein (HSP 70) expression in the tropical reef coral Goniopora djiboutiensis. Journal of Thermal Biology 1997, 22: I I-19.

9. Edge SE, Morgan MB, Gleason DF, Snell TW: Development of a coral cDNA array to examine gene expression profiles in Montastraea faveolata exposed to environmental stress. Mar Pollut Bull 2005, 5 I:507-523.

10. Lesser MP: Oxidative stress causes coral bleaching during exposure to elevated temperatures. Coral Reefs 1997, 16:187-192.

II. Downs CA, Mueller E, Phillips S, Fauth JE, Woodley CM: A molecular biomarker system for assessing the health of coral (Montastraea faveolata) during heat stress. Mar Biotechnol (NY) 2000, 2:533-544

12. Weis VM: Cellular mechanisms of Cnidarian M: stress causes the collapse of symbiosis. J Exp Biol 2008, 21 I:3059-3066.

13. Jones RJ, Hoegh-Guldberg O, Larkum AWD, Schreiber U: Temperature-induced bleaching of corals begins with impairment of the $\mathrm{CO}_{2}$ fixation mechanism in zooxanthellae. Plant, Cell \& Environment 1998, 21:1219-1230.

14. Pechenik JA: On the advantages and disadvantages of larval stages in benthic marine invertebrate life cycles. Marine Ecology-Progress Series 1999, 177:269-297.

15. Negri A, Marshall P, Heyward A: Differing effects of thermal stress on coral fertilization and early embryogenesis in four Indo Pacific species. Coral Reefs 2007, 26:759-763.

16. Bassim KM, Sammarco PW: Effects of temperature and ammonium on larval development and survivorship in a scleractinian coral (Diploria strigosa). Marine Biology 2003, I 42:24I-252.

17. Grasso L, Maindonald J, Rudd S, Hayward D, Saint R, Miller D, Ball E: Microarray analysis identifies candidate genes for key roles in coral development. BMC Genomics 2008, 9:540.

18. Sunagawa S, DeSalvo MK, Voolstra CR, Reyes-Bermudez A, Medina M: Identification and Gene Expression Analysis of a Taxonomically Restricted Cysteine-Rich Protein Family in ReefBuilding Corals. PLOS ONE 2009, 4:e4865-e4865.

19. Sorger PK, Pelham HR: Purification and characterization of a heat-shock element binding protein from yeast. EMBO J 1987, 6:3035-3041.

20. Clos J, Westwood JT, Becker PB, Wilson S, Lambert K, Wu C Molecular cloning and expression of a hexameric Drosophila heat shock factor subject to negative regulation. Cell 1990, 63: $1085-1097$.

2I. Trinklein ND, Murray JI, Hartman SJ, Botstein D, Myers RM: The Role of Heat Shock Transcription Factor I in the Genomewide Regulation of the Mammalian Heat Shock Response. Mol Biol Cell 2004, I 5: 1254-I26I.

22. Nelson RE, Fessler LI, Takagi Y, Blumberg B, Keene DR, Olson PF, Parker CG, Fessler JH: Peroxidasin: a novel enzyme-matrix protein of Drosophila development. Embo J 1994, 1 3:3438-3447.

23. Persengiev SP, Green MR: The role of ATF/CREB family members in cell growth, survival and apoptosis. Apoptosis 2003, 8:225-228.

24. Wei $Y$, Jiang J, Sun $M$, Chen $X$, Wang $H$, Gu J: ATF5 increases cisplatin-induced apoptosis through up-regulation of cyclin D3 transcription in HeLa cells. Biochem Biophys Res Commun 2006, 339:59|-596.

25. Liu H, Bowes lii RC, Water B van de, Sillence C, Nagelkerke JF, Stevens JL: Endoplasmic Reticulum Chaperones GRP78 and Calreticulin Prevent Oxidative Stress, Ca2+ Disturbances, and Cell Death in Renal Epithelial Cells. J Biol Chem 1997, 272:21751-21759.

26. Hayes JD, Pulford $D$ ]: The glutathione S-transferase supergene family: regulation of GST and the contribution of the isoenzymes to cancer chemoprotection and drug resistance. Crit Rev Biochem Mol Biol 1995, 30:445-600.

27. Lioudyno M, Skoglosa Y, Takei N, Lindholm D: Pituitary adenylate cyclase-activating polypeptide (PACAP) protects dorsal root ganglion neurons from death and induces calcitonin gene-related peptide (CGRP) immunoreactivity in vitro. J Neurosci Res 1998, 51:243-256.

28. Vaudry D, Pamantung TF, Basille M, Rousselle C, Fournier A, Vaudry $\mathrm{H}$, Beauvillain JC, Gonzalez BJ: PACAP protects cerebellar granule neurons against oxidative stress-induced apoptosis. Eur J Neurosci 2002, I5: |45 I- 4460
29. Schallreuter KU, Gibbons NC, Zothner C, Abou Elloof MM, Wood JM: Hydrogen peroxide-mediated oxidative stress disrupts calcium binding on calmodulin: more evidence for oxidative stress in vitiligo. Biochem Biophys Res Commun 2007, 360:70-75.

30. Bell J, Neilson L, Pellegrini M: Effect of heat shock on ribosome synthesis in Drosophila melanogaster. Mol Cell Biol 1988, 8:91-95.

3I. Herruer MH, Mager WH, Raue HA, Vreken P, Wilms E, Planta RJ: Mild temperature shock affects transcription of yeast ribosomal protein genes as well as the stability of their mRNAs. Nucleic Acids Res 1988, 16:7917-7929.

32. Lachner M, O'Carroll D, Rea S, Mechtler K, Jenuwein T: Methylation of histone $\mathrm{H} 3$ lysine 9 creates a binding site for HPI proteins. Nature 2001, 410:116-120.

33. Su C, Gao G, Schneider S, Helt C, Weiss C, O'Reilly MA, Bohmann $D$, Zhao J: DNA damage induces downregulation of histone gene expression through the GI checkpoint pathway. The EMBO Journal 2004, 23: I I33-1 I43.

34. luchi S: Three classes of $\mathbf{C} \mathbf{2} \mathbf{H} 2$ zinc finger proteins. Cell Mol Life Sci 200I, 58:625-635.

35. Akhtar A, Becker PB: The histone H4 acetyltransferase MOF uses a C2HC zinc finger for substrate recognition. $E M B O R e p$ 200I, 2:II3-II8.

36. Krichevsky A, Gutgarts H, Kozlovsky SV, Tzfira T, Sutton A, Sternglanz R, Mandel G, Citovsky V: C2H2 zinc finger-SET histone methyltransferase is a plant-specific chromatin modifier. Dev Biol 2007, 303:259-269.

37. Schiaffonati L, Rappocciolo E, Tacchini L, Cairo G, Bernelli-Zazzera A: Reprogramming of gene expression in postischemic rat liver: induction of proto-oncogenes and hsp 70 gene family. J Cell Physiol 1990, 143:79-87.

38. Salo DC, Donovan CM, Davies KJ: HSP70 and other possible heat shock or oxidative stress proteins are induced in skeletal muscle, heart, and liver during exercise. Free Radic Biol Med 1991, I I:239-246.

39. Gourlay CW, Ayscough KR: The actin cytoskeleton: a key regulator of apoptosis and ageing? Nat Rev Mol Cell Biol 2005, 6:583-589.

40. Miller MW, Szmant AM, Precht WF: Lessons Learned from Experimental Key-Species Restoration. In Coral Reef Restoration Handbook CRC Press; 2006:219-234.

4I. Szmant AM, Miller MW: Settlement preferences and post-settlement mortality of laboratory cultured and settled larvae of the Caribbean hermatypic corals Montastraea faveolata and Acropora palmata in the Florida Keys, USA. Proc I0th Int Coral Reef Symp; 2005 2005:43-49.

42. Randall CJ, Szmant AM: Elevated temperature affects development, survivorship, and settlement of the elkhorn coral, Acropora palmata (Lamarck 1816). Biol Bull in press.

43. Schwarz JA, Brokstein PB, Voolstra C, Terry AY, Miller DJ, Szmant AM, Coffroth MA, Medina M: Coral life history and symbiosis: functional genomic resources for two reef building Caribbean corals, Acropora palmata and Montastraea faveolata. BMC Genomics 2008, 9:97.

44. Saeed Al, Sharov V, White J, Li J, Liang W, Bhagabati N, Braisted J, Klapa M, Currier T, Thiagarajan M, et al.: TM4: a free, open-source system for microarray data management and analysis. Biotechniques 2003, 34:374-378

45. Edgar R, Domrachev M, Lash AE: Gene Expression Omnibus: NCBI gene expression and hybridization array data repository. Nucl Acids Res 2002, 30:207-2 I0.

46. Townsend JP, Hartl DL: Bayesian analysis of gene expression levels: statistical quantification of relative mRNA level across multiple strains or treatments. Genome Biol 2002, 3:RESEARCH007I.

47. Page RDM: TreeView: An application to display phylogenetic trees on personal computers. Computer Applications in the Biosciences 1996, I 2:357-358. 